\title{
The framework of usefulness evaluation of English coursebook for young learners
}

\author{
Ling Lin \\ Foreign Languages School, China Three Gorges University, Yichang City, Hubei Province, China
}

\section{Email address:}

Windbell621@gmail.com

\section{To cite this article:}

Ling Lin. The Framework of Usefulness Evaluation of English Coursebook for Young Learners. Education Journal. Vol. 3, No. 6, 2014, pp. 361-365. doi: 10.11648/j.edu.20140306.16

\begin{abstract}
Course book plays a vital role in English teaching. No one could deny it that teaching young learners and adults are not identical. However, until now, the study of language course book evaluation has been focusing on learning materials for adults. The study presented here means to give some insightful analysis of course book evaluation and brings forth a framework for language course book evaluation.
\end{abstract}

Keywords: English Coursebook, Young Learners, Usefulness Evaluation

\section{Introduction}

According to Cunningsworth (2002), textbooks are best seen as a resource in achieving aims and objectives that have already been set in terms of learners' needs. Cunningworth makes a summary of multiple roles textbooks play in English language teaching. (2002, p7): A resource for presenting materials (spoken and written);A resource for providing activities so that learners can practice; A reference source for learners on grammar, vocabulary, pronunciation; A resource for self-directed learning or self-access work. It has to be recognized that teaching materials can exert considerable influence on language teaching. Therefore, it is of crucial importance that careful selection be made and the materials should reflect the aims, methods and values of the teaching program.

How to manipulate the process of evaluating textbooks? There are some guidelines to follow. According to Cunningworth (2002), there are four guidelines in approaching any materials evaluation exercise: textbooks should correspond to learners' needs, and match the aims and objectives of the language-learning program; textbooks should reflect the uses which learners will make of the language and we should select textbooks which will help to equip students to use language effectively for their own purpose; textbooks should take account of students' needs as learners and should facilitate their learning processes; textbooks should have a clear role as a support for learning for they mediate between the target language and the learner like teachers.
For the English course book for young learners, the evaluation criteria should be: textbooks should take account of students' needs as learners and should facilitate their learning processes. The question is how well the Cambridge Young Learners English have met students' needs and how well the Cambridge Young Learners English could facilitate their learning process? Are the textbooks age-scaffolding? Does the sequencing of language content facilitate language development of young learners? In a word, how well the language content is organized to promote English learning of Chinese children?

\section{Theoretical Base for Evaluation}

\subsection{Young Learners (Age Factor)}

Children differ from adults qualitatively. Language development is always viewed as an aspect of cognitive development of children. Two great men should be mentioned here due to their great contribution in this field. One is the founder of cognitive-development theory Jean Piaget and the other is the founder of social-historical theory Lev Semenovich Vygotsky.

As far as language is concerned, Piaget (1967) theory maintains that language reflects thinking processes, and helps to facilitate cognitive development. Language is both a tool to aid thinking and a vehicle to permit communication and the expressions of ideas. Piaget suggested that language allows children to represent the world mentally, and thus frees their thought from the immediacy of perception. People 
are able to talk about events and objects that are never directly perceived, and the ability to do this allows the child to move from sensori-motor to pre-operational intelligence. However, the Piaget's theory perceives that child's cognitive development is an interaction between individual child and the environment, which gives little consideration of the social context in which the child grows up. In this theory, cognitive competence and a child's ability to learn heavily rely upon a maturation process. Learning is an individual process and the influence from education follows maturation. Contrary to Piaget, Vygotsky considered learning as a shared or joint process in a responsive social context. In Vygotsky's framework, children are capable of far more competent performance when they have proper assistance (scaffolding learning) from adults.

Based on Piaget and Vygotsky theories, teachers are advised to provide a collaboration style of learning models with students instead of traditional learning models in which teachers instead of students dominate the classroom. McGee and Richgels (1996) argued that children build new concepts by interacting with others who either provide feedback for their hypotheses or help them accomplish a task.

\subsection{Language Acquisition}

Studies in first language acquisition shed some light on second language acquisition regarding children who fall in within the limit of critical period. Later on, the researches on child's language development in linguistic subsystems will give some insight into child's learning a second language.

\subsubsection{Phonological Development}

A child must have learnt the physiological and acoustic phonetics before organizing them into a higher-level system: phonology. We can find evidence of that phonetic repertory in babbling stage when children make a large array of sounds.

In learning to pronounce, a child must acquire a sound system including phonology and phonetics. Phonetics acquisition is to acquire the realization of each sound while phonology acquisition is to acquire the systematic way of organizing those sounds together. Obviously, the phonology acquisition is more abstract for children must derive more abstract phonological units from adult speech: first intonations, then syllables, then distinctive features and finally consonant-vowel segment (Moskowitz, 1998). The research has indicated that intonation contours are the earliest to acquire by children. And it is even said that the language environment can be identified from the child's babbling intonation (Moskowitz, 1998). Moskowitz (1998) also suggested from her work that unanalyzed syllables appear to be the basic unit of the sound system when there are relatively few words in a child's repertory. The syllable types for children's first words are VC, CVC and CV (C: consonant; V: vowel) (Stark, 1980). As we have said, children will not pay much attention to the details of pronunciation until they have acquired phonological system. Jakobson (1968) suggested that children don't acquire individual sounds in an orderly way but through the distinctive features of sound. That is to say, they learn sounds through minimal differences or contrasts between sounds.

In a word, children's phonetic system will be constantly elaborated only after they have acquired phonological system of the language. That is not to say phonological development precedes phonetic learning. In fact, the evidence of phonetic repertory can be found as early as babbling period. Research also indicates that children present some acquisition sequence as for the phonological features. The intonation is the earliest while the consonant-vowel segment is the last to acquire. The early consonant-vowel combinations are limited to only three types of syllable structures: $\mathrm{CV}, \mathrm{VC}$, and CVC. As for individual sounds pronunciation, Jakbson (1968) asserted that children acquire sounds via distinctive features. At last, children successfully build a phonological representation of the language to manipulate all phonetic variations of language and learn to produce each one precisely and automatically.

\subsubsection{Vocabulary Development}

Children's average vocabulary size increases rapidly between the age of one-and-a-half and six-and-a-half. According to the work of Madorah E. Smith of the university Hawaii, children's vocabulary increases from less than 200 to nearly about 2600 at the age of six and a half.

Vocabulary size is the landmark of children's language development and important criteria for children's cognitive development too (Zhou Guoguang, Wang Baohua). L.W. Stern, M.E. Smith and C. Buhler are devoted to the research concerning children's vocabulary development. According to Stern, children's vocabulary will grow from o to 100 at 1.5 , $300-400$ at 2, 1000-1100 at 3,1600 at 4, 2200 at about 5, and 2500 to 3000 at 6 . Smith and Buhler also got similar results from their respective researches. However, Buhler got a range for vocabulary that average English-speaking children obtain at certain age (table 3.2.3-1). They also found that content words proportioned over $90 \%$ of average children's vocabulary (Zhou Guoguang, Wang Baohua).

How could children build their vocabulary so rapidly? What are the strategies children adopt in vocabulary learning? Researchers have discovered that children are supported by fast mapping in their early childhood which means they can connect a new word with an underlying concept after only a brief encounter, a process called fast mapping. Though toddlers comprehend new label at an impressive rate, they still need more repetitions of the word's use across several situations than preschoolers, who better remember and categorize speech-based information (Berk, 2004). Preschoolers figure out the meanings of words by contrasting them with words they already know and assigning the new label to a gap in their vocabulary (Clark, 1990). But how children discover which concept each word picks out is not yet discovered. One speculation is that children adopt a mutual exclusivity bias in early period of vocabulary growth, assuming that each new word refers to an entirely separate category. But exclusivity bias cannot account for what children do when objects have more than one name. Children draw on other aspects of language for help-- syntactic bootstrapping. 
They discern meaning of a new word by observing how it is used in the structure of sentence. They also make use of adults' social cues such as gestures and directly provided information about word meanings (Berk, 2004). Once they have enough vocabulary, they coin new words based on ones they already know (Clark, 1995). Metaphors which permit them to communicate in vivid and memorable ways are adopted too by children to extend language meanings. The metaphors young preschoolers use and understand involve concrete and sensory comparisons such as "clouds are pillows" but they can make non-sensory comparisons such as "friends are like magnets" once their vocabulary and knowledge expand (Karadsheh, 1991). As children grow older, school-age children enlarge their vocabulary through analyzing the structure of complex words. For example, they derive meanings of "happiness" from "happy" (Anglin, 1993). They also figure out many more word meanings from context (Nagy \& Scott, 2000).

\subsubsection{Syntactic Development}

Foster-Cohen (1999) gives a summary from the age two to five for English-speaking children. It can be seen that the syntax development for children goes along a generally identical developmental path.

Table 1. Syntax development

\begin{tabular}{ll}
\hline Age & Grammar development \\
\hline 2-year & $\begin{array}{l}\text { Declarative sentences most are statements. they pose questions } \\
\text { more by changing intonation;the third person singular } \\
\text { Plurals, begin to use negate sentences along the path of "no at the } \\
\text { beginning-contracted negatives; begin to use auxiliary verbs such } \\
\text { as do and will; }\end{array}$ \\
3-year \\
4-year & $\begin{array}{l}\text { similar path } \\
\text { Verbal morphology is still a tough task; complex conditional } \\
\text { clauses, relative clauses; wh-movement occur in the relative } \\
\text { clauses }\end{array}$ \\
\hline
\end{tabular}

\subsection{Second Language Acquisition}

Age has some relevancy to accounting for children's success in language acquisition (Chomsky's LAD and critical period hypothesis). Whether age plays a vital role in second language acquisition is still under debate. It is only agreed that there is some evidence for an age-related decline in language learning abilities (Gass \& Selinker, 2001). Attention will be focused on how much similarity children share in first language acquisition and second language acquisition other than continuing the debate about whether age is the predominant factor for child's success in second language acquisition.

For children who acquire their second language after they have mastered their first language in natural setting, can they achieve the near-native language proficiency? Do they learn by the same path? According to Hakuta (1999) it generally takes 3 to 5 years to become as competent in the second language as their native-speaking playmates of the same age for those who acquire second language after they have fully acquired their first language. Wong-Fillmore (1991) described that children learn second language by learning large chunks of speech used in communication and only later are the chunks analyzed into components. The earlier work of Ravem (1968) and Dato (1971), as well as the evidences from the studies of Ervin-Tripp (1974) and Natalicio and Natalicio (1971) suggested that the developmental stages are much the same as monolingual children. Studies (Dulay and Burt, 1974) show that the order in which a language is learned by children in terms of syntax and morphemes for example is highly similar in many cases between first language and second language.

Above all, we have focused our discussion on the bilingual development for children in natural setting. How do children learn second language in school setting? Do they learn by a similar process in the way preschool children learn? An obvious difference is that children learning in school are older and have at their disposal cognitive and mnemonic devices that young children lack. Older children know more about language than young children and can apply more sophisticated linguistic and cognitive strategies. Thus school children seem to be more likely than younger children to use strategy of resorting to structures of their first language when faced with linguistic puzzles in the second language. This seems especially true if the children have little contact with native speakers of the target language (Mclaughlin, 1984). Therefore, it is obvious that children learning a second language in a classroom setting are less likely than preschool children to follow regular developmental sequences in their acquisition of constructions such as the negative, article, pronoun, and certain grammatical markers. (A number of reasons have been given for these deviations from the developmental path, principally dynamic methods used by the teacher to force learners to acquire constructions before they are ready to learn them, language drills that lead to short-term learning of constructions that are quickly forgotten, and an artificially limited range of language in the teacher's speech.) However, that is not to say children learning a second language in a classroom setting will inevitably follow a different developmental sequence in the acquisition of grammatical constructions than has been observed in the speech of preschool children (Mclaughlin, 1984). According to Mclaughlin (1984), research has shown that some grammatical constructions develop in the way that reflects patterns found in first language acquisition. The consistence may be accounted for by several reasons. Mclaughlin (1984) argued that learners acquire second language in two types of processes. On one hand, they formulate hypothesis and revise them on the basis of language-specific cognitive mechanisms, which are thought to be universal to all language learning and are perhaps based on innate-language-specific cognitive mechanisms. The other type of process is to adopt some tactics which refers to some techniques learners use to solve some temporary and immediate problems in language learning tasks. However, the tactics may be chosen deliberately according to individual's demands. Thus the fact that constructions found in the speech of school children learning a second language are similar to developmental sequences found in the speech of monolingual speakers of the language can be attributed to the application of language learning.

Older learners may be able to short-cut natural sequences 
because of their greater capacity to make grammatical judgments and treat language abstractly. The older learners may be more efficient in using such tactics such as rule isolation and rote memorization than younger learners. Thus, considerations as how material is to be introduced and the presentation of grammatical items must be carefully made for pedagogical practice.

\section{Framework of Evaluation}

The concerning researches in psychology, language acquisition, second language acquisition has given us some insight into the study of second language teaching and learning towards young learners. Generally speaking, the designer of a course book for young learners should take the special psychological development and principles of linguistic development into account. Otherwise, the course book may not be as useful as the designer expects.

A checklist is useful when approaching textbook evaluation (from Cunningsworth, 2002). Language teaching is tightly related with the learning of language content including grammar, phonology and vocabulary. Following a checklist will help us to gain deeper understanding of the organization. The checklist is put in three aspects: linguistic factors (grammar, phonology, vocabulary), layout factor, activity factor.

1 Grammar:

Are grammar items presented in small units for easy learning?

Is there an emphasis on language form?

Is there an emphasis on language use (meaning)?

2 Phonology:

Does the textbook include material for pronunciation work? If so what is covered: individual sounds, word stress, sentence stress, intonation?

Is the pronunciation work built on upon other types of word, such as listening, dialogue practice, etc or does it stand separately?

How much terminology is used? Is it comprehensible to the learners?

Is the phonemic alphabet used?

Does the material use a diagrammatic system to show stress and intonation?

Are there cassettes for pronunciation practice? If so, do they provide good models for learners?

3 Vocabulary:

How much vocabulary is taught?

Is there any principled basis for selection of vocabulary?

Is vocabulary presented in a structured, purposeful way?

4 Layout:

Are the learning materials laid out in a scaffolding way to help children learn?

5 Activities

Are learning activities designed in a supportive way?

\section{Conclusion}

Language pedagogy is subject to influence from linguistics but seldom can we directly apply the linguistic researches into language teaching. Textbook evaluation is a huge project which may get involved into a complex checklist. What the author presents here is just an observation from angles in language acquisition. In fact, the application of researches in language development regarding children still needs to find its proper place in language teaching. But the thesis also provides a framework as to how to select, grade and sequence language content. For any textbook designer, any selection or omission should have its own reasons. For textbook designers, not only should we consider the features of their learning strategy, their psychological states, but also their natural sequence.

\section{References}

[1] Berk, E. L. (2004) Infants, Children and Adolescents. Pearson education Asia Limited and Peking University Press

[2] Clark, E. V. (1990). On the Pragmatics of Contrast. Journal of Child Language, 17, 417-431

[3] Clark, E. V. (1995). The Lexicon and Syntax. In J. L., Miller \& P. D. Eimas (Eds). Speech, Language, and Communication (pp303-337) San Diego: Academic Press

[4] Cook, V. (2000). Second Language Learning and Language Teaching. Beijing: Edward Arnold Limited \& Foreign Language Teaching and Research Press

[5] Cunningham, A. E. \& Stanovich, K. E. (1998). What Reading Does for the Mind. American educator, Spring/ Summer, 8-15

[6] Cunningworth, A. (2002). Choosing Your Coursebook. Shanghai: Shanghai Foreign Language Education Press

[7] Curtiss, S. (1977). Genie: A Psycholinguistic Study of Modern Day "Wild Child". N.Y.: Academic Press

[8] Foster-Cohen, S. H., (1999) An Introduction to Child Language Development. London: Longman

[9] Gass, S. M. \& Selinker, L (2001). Second Language Acquisition-An Introductory Text. ( $2^{\text {nd }}$ edition). Mahwah, NJ: ErlBaum

[10] Hakakuta, K. (1999). The Debate on Bilingual Education. Developmental and Behavioral Pediatrics. 20,36-37

[11] Hausfather, Samuel J., (1996). Vygotsky and Schooling: Creating a Social Contest for Learning. Action in Teacher Education. (18). 1-10

[12] Horgan, D. (1978). The Development of the Full Passive. Journal of Child Languages, 5, 65-80

[13] Hughes, P. F. \& Noppe, L. D. \& Noppe, I. (1996) Child Development. Prentice-Hall Inc.

[14] Jakobson, R. (1968). Child Language, Aphasia, and Phonological Universals. The Hague: Mouton. (Originally published 1941)

[15] Karadsheh, R. (1991). This Room is a Junkyard!: Children's Comprehension of Metaphorical Language. Paper presented at the biennial meeting of the Society for Research in Child Development, Seattle, WA. 
[16] Lenneberg, E. H. (1967). Biological Foundations of Language. Wiley

[17] Maratsos,M. (1998). The Acquisition of Grammar. In D. Kuhn \& R.S. Siegler (Eds), Hnadbook of Child Psychology: Theoretical Models of Human Development $\left(5^{\text {th }}\right.$ ed., pp. 255-308). vol. 1. New York: Wiley.

[18] McGee, L. M. \& Richgels, D. J. (1996). Literacy's Beginners: Supporting Young Readers and Writers (2nd Ed.). Boston: Allynand Bacon

[19] McLaughlin, B.(1984). Second-Language Acquisition in Childhood. Lawrence Erlbaum Associate

[20] Moskowitz, B. A. (1998). The Acquisition of Language. In V. P. Clark, P. A. Eschholz, \& A. F. Rosa (Eds.), Language: Readings in Language and Culture (6th ed.). Boston: Bedford/St. Martin's.

[21] Nagy, W.E. and Herman, P.A. (1987). Breadth and Depth of Vocabulary Knowledge: Implications for Acquisition and Instruction. In M. McKeown and M. Curtis (Eds.), The Nature of Vocabulary Acquisition. Hillsdale, NJ: Erlbaum Associates.

[22] Nagy, W. E. \& Scott, J. A. (2000). Vocabulary Processes. In M. L. Kamil \& p. B. Mosenthal (Eds), Handbook of Reading Research (vol. 3, pp. 269-284). Mahwah, NJ: Erlbaum.

[23] Neville, H. J. \& Bruer, J. T. (2001). Language Processing: How Experience Affects Brain Organization. In. D. B. Bailey, Jr. J. T. Bruer, F.J. Symons, \& J. W. Lichtman (Eds.). Critical Thinking about Critical Periods. (pp151-172). Baltimore: Paul H. Brookes

[24] Oller, D. K. (2000). The Emergence of the Speech Capacity. Mahwah, NJ: Erlbaum.

[25] Piaget, J. (1967). Six Psychological Studies. N. Y. Vintage

[26] Pinker S. (2004). The Language Instinct. Shangtou University Press

[27] Pinker S. (1984). Language Learnability and Language Development. Cambridge, Mass.: Harvard University Press

[28] Richards, J. C., Platt, John \& Platt, Heidi (2000). Longman Dictionary of Language Teaching \& Applied Linguistics. Beijing: Foreign Language Teaching and Research Press

[29] Stark, R. (1980) Towards a Theory of Phonological Development, Lingua, 68, 3-38

[30] Vygotsky (1986) Thought and Language Cambridge, MA: MIT Press

[31] Wong-Fillmore, L. (1991). Second-Language Learning in Childhood: A Model of Language Learning in Social Context. In E. Bialystok (Ed.), Language Processing in Bilingual Children (pp. 49-69). Cambridge: Cambridge University Press

[32] Zhou Guoguang \& Wang Baohua (2001), child's syntax-the study into child's language development and acquisition, Beijing Language and Culture University Publisher 